\title{
Silverleaf Nightshade (Solanum elaeagnifolium), a Reservoir Host for 'Candidatus Liberibacter solanacearum', the Putative Causal Agent of Zebra Chip Disease of Potato
}

Jenita Thinakaran, Texas A\&M AgriLife Research, Weslaco 78596; Elizabeth Pierson, Department of Horticultural Sciences, Texas A\&M University, College Station 77843; Madhurababu Kunta, Texas A\&M University-Kingsville Citrus Center, Weslaco 78599; Joseph E. Munyaneza, United States Department of Agriculture-Agricultural Research Service (USDA-ARS), Wapato, WA, 98951; Charlie M. Rush, Texas A\&M AgriLife Research and Extension Center, Amarillo 79106; and Don C. Henne, Texas A\&M AgriLife Research, Weslaco 78596

\begin{abstract}
Thinakaran, J., Pierson, E., Kunta, M., Munyaneza, J. E., Rush, C. M., and Henne, D. C. 2015. Silverleaf nightshade (Solanum elaeagnifolium), a reservoir host for 'Candidatus liberibacter solanacearum', the putative causal agent of zebra chip disease of potato. Plant Dis. 99:910-915.

Zebra chip disease of potato is caused by the bacterial pathogen 'Candidatus Liberibacter solanacearum' and is a growing concern for commercial potato production in several countries in North and Central America and New Zealand. ' $\mathrm{Ca}$. L. solanacearum' is vectored by the potato psyllid Bactericera cockerelli, which transmits the pathogen to several cultivated and wild solanaceaous host plants. Silverleaf nightshade (SLN), Solanum elaeagnifolium, is a common weed in the Lower Rio Grande Valley of Texas and a host for both the potato psyllid and ' $\mathrm{Ca}$. L. solanacearum'. SLN plants were successfully inoculated with ' $\mathrm{Ca}$. L. solanacearum' under laboratory conditions. Retention studies demonstrated that ' $\mathrm{Ca}$. L. solanacearum'-infected SLN planted in the field in January 2013, concurrent with commercial potato planting, retained the pathogen under field conditions throughout the year despite extensive dieback during summer. The

presence of ' $\mathrm{Ca}$. L. solanacearum' was confirmed in leaves, roots, and stolons of SLN plants collected the following year using polymerase chain reaction. Acquisition assays using B. cockerelli adults also revealed that SLN retained the pathogen. Transmission studies determined that $B$. cockerelli can acquire ' $C a$. L. solanacearum' within a 2-week acquisition access period on ' $\mathrm{Ca}$. L. solanacearum'-infected SLN and subsequently transmit the pathogen to potato. These results demonstrate that SLN plants can serve as a reservoir for ' $\mathrm{Ca}$. L. solanacearum', providing a source of inoculum for B. cockerelli adults colonizing potato the next season. The presence of SLN plants all year round in the LRGV makes the weed an epidemiologically important host. These findings underscore the importance of eradicating or managing SLN plants growing in the vicinity of potato fields to prevent spread of ' $C a$. L. solanacearum' and damage caused by zebra chip.
\end{abstract}

Zebra chip (ZC) disease is an economically important disease of potatoes impacting potato production in the United States, Central America, and New Zealand (Crosslin et al. 2010, 2011, 2012a,b; Liefting et al. 2008; Munyaneza et al. 2007a; Secor and Rivera-Varas 2004). ZC-infected potato plants exhibit yellow to purple discoloration of the foliage, proliferation of auxiliary buds with shortened internodes, swollen nodes, and aerial tubers accompanied by sudden death of plants. A diagnostic symptom of $\mathrm{ZC}$ is the appearance of a brownstriped discoloration along the medullary rays of tubers, which becomes highly pronounced after they are fried (Munyaneza et al. 2007a,b). ZC is caused by the bacterium 'Candidatus Liberibacter solanacearum' (Hansen et al. 2008; Liefting et al. 2008, 2009a,b). Thus far, Bactericera cockerelli is the only known vector of this pathogen to potato and other solanaceous species (Hansen et al. 2008; Secor et al. 2009). 'Ca. L. solanacearum' also may be transmitted transovarially from $B$. cockerelli females to offspring (Hansen et al. 2008). $B$. cockerelli adults are able to acquire ' $C a$. L. solanacearum' within $6 \mathrm{~h}$ of an acquisition access period on ' $\mathrm{Ca}$. L. solanacearum'-infected potato plants (Munyaneza 2012) and may be influenced by the host plant from which they acquired the pathogen (Sengoda et al. 2013). Furthermore, B. cockerelli adults can transmit ' $\mathrm{Ca}$. L. solanacearum' more efficiently than nymphs (Buchman et al. 2011b) and require

Current address of J. Thinakaran: USDA-ARS, Wapato, WA, 98951.

Corresponding author: J. Thinakaran;

E-mail: Jenita.Thinakaran@ars.usda.gov

Accepted for publication 24 January 2015.

http://dx.doi.org/10.1094/PDIS-12-14-1254-RE

(C) 2015 The American Phytopathological Society a latent period of about 2 weeks before they can transmit the pathogen to healthy plants (Sengoda et al. 2013). Previous work demonstrated that, in addition to potato, $B$. cockerelli readily transmits ' $C a$. L. solanacearum' to other cultivated solanaceous crops, including tomato and pepper (Hansen et al. 2008; Liefting et al. 2008, 2009a,b). Moreover, it has been shown that the adults may transmit ' $\mathrm{Ca}$. $\mathrm{L}$. solanacearum' in as little as $1 \mathrm{~h}$ after settling (Buchman et al. 2011a). Although much emphasis has been placed on the ability of $B$. cockerelli to acquire and transmit ' $C a$. L. solanacearum' among cultivated solanaceous hosts, relatively little is known regarding its use of wild alternative host plants.

Alternate hosts, especially solanaceous weeds, may contribute significantly to the epidemiology of ZC by serving as refuges for the insect pest and reservoirs for the pathogen (Henne et al. 2010). Very little is known about the role of solanaceous weeds in facilitating ' $C a$. L. solanacearum' persistence in the absence of cultivated hosts. Several wild solanaceous species have been reported to serve as breeding and overwintering hosts for potato psyllids. For example, Romney (1939) reported that migrating psyllid populations breed on Lycium spp. for several hundred miles along the Rio Grande drainage above Laredo, TX. B. cockerelli also has been reported on a number of other wild and cultivated solanaceous hosts that co-occur with the psyllid throughout its range (Crawford 1914; Essig 1917; Janes 1939; Knowlton and Thomas 1934; Pletch 1947; Wallis 1955). More recently several noncultivated wild solanaceous plants were reported to serve as alternative hosts of both $B$. cockerelli and ' $\mathrm{Ca}$. L. solanacearum' (Henne et al. 2010; Wen et al. 2009).

In this study, we focus on the potential for silverleaf nightshade (SLN) to serve as a pathogen reservoir for ' $\mathrm{Ca}$. L. solanacearum' inoculum between potato crops in the Lower Rio Grande Valley (LRGV) of Texas. SLN is a broadleaved herbaceous and woody perennial solanaceous weed that is native to northeast Mexico and the southwestern United States, where it is widespread and abundant 
(Robinson et al. 1978). Because SLN is so abundant and difficult to eradicate, the possibility of SLN serving as a significant source of primary inoculum would have important implication for ZC disease management. The main objectives of the study were to assess (i) whether SLN can be infected with ' $C a$. L. solanacearum' by $B$. cockerelli adults; (ii) whether SLN plants infected with ' $C a$. L. solanacearum' during one planting season can retain the pathogen and serve as an ' $\mathrm{Ca}$. L. solanacearum' reservoir, contributing viable inoculum to the next planting season; and (iii) whether B. cockerelli adults can acquire ' $C a$. L. solanacearum' from infected SLN and transmit it to healthy potato

\section{Materials and Methods}

Source of plants. SLN seeds were collected from fully mature fruits on SLN plants growing along roadsides close to the Texas A\&M AgriLife experiment station in Weslaco, TX. Seeds were planted individually in cone-shaped pots measuring 3 by 3 by $4 \mathrm{~cm}$ filled with Metro-Mix 360 growth medium (Sungro Horticultural Distribution, Bellevue, WA) and maintained in a greenhouse at 28 to $30^{\circ} \mathrm{C}$ under natural light. When seedlings were 1 to 2 weeks old, they were transplanted into 10-cm-diameter square, black plastic pots filled with the same potting mix. SLN plants used in the experiments were 5 to 6 weeks old. Potato seed tubers ('Atlantic') obtained from J. W. Farms (Edinburg, TX) were cut in pieces, allowed to suberize, and planted in square 10 -cm-diameter black plastic pots filled with the same potting mix as mentioned above. Potato plants used in the experiments were 3 to 4 weeks old. All plants (potato and SLN) were fertilized once a week and watered three times a week or as needed.

Source of insects. 'Ca. L. solanacearum'-infected colony. B. cockerelli adults were originally collected from a potato field at the Texas A\&M AgriLife Experiment Station in Weslaco, TX in 2009 and were continuously reared over several generations on ' $\mathrm{Ca}$. L. solanacearum'-infected potato plants within BugDorm insect cages (60 by 60 by $60 \mathrm{~cm}$, catalog number BD2120F; MegaView Science Co., Taichung, Taiwan). The cages were kept inside an insectary maintained at 25 to $27^{\circ} \mathrm{C}, 65$ to $70 \%$ relative humidity, and a photoperiod of $16 \mathrm{~h}$ of light and $8 \mathrm{~h}$ of darkness. The colonies were tested for ' $\mathrm{Ca}$. L. solanacearum' once every 2 months using conventional polymerase chain reaction (cPCR) (Buchman et al. 2011b), and 90 to $100 \%$ of the insects always tested positive for ' $\mathrm{Ca}$. L. solanacearum'.

'Ca. L. solanacearum'-free colony. B. cockerelli adults originally collected and isolated from Texas fields in 2011 were obtained from the United States Department of Agriculture (USDA) Agricultural Research Service, Wapato, WA and were confirmed to be ' $C a$. L. solanacearum'-free via PCR testing. The ' $\mathrm{Ca}$. L. solanacearum'-free insects were maintained on potato plants inside BugDorm cages under conditions identical to the ' $C a$. L. solanacearum'-infected colony but in an insectary separated from the ' $C a$. L. solanacearum'-infected colony room. ' $C a$. L. solanacearum'-free $B$. cockerelli colonies were tested once every month for ' $\mathrm{Ca}$. L. solanacearum' using cPCR to verify they were free of the bacterium.

' $\mathrm{Ca}$. L. solanacearum' inoculation to SLN plants using B. cockerelli adults. SLN (100 plants, 5 to 6 weeks old) grown under greenhouse conditions within cages (to prevent accidental infection) were selected for the study. Seven $B$. cockerelli adults from the ' $C a$. L. solanacearum'-infected colony were restrained within white organza pouches (7.5- by $10-\mathrm{cm}$ organza drawstring pouches, handmade, supplied from various sources) tied to a lower-tier leaf on each of the 100 plants. The netted bags ensured that insects had room to feed and move about on the leaves but not escape. After a 1-week inoculation access period (IAP), the entire bag containing $B$. cockerelli adults along with the leaf was clipped off the plant, as demonstrated for potato and tomato (Levy et al. 2011). Three weeks after initial inoculation, the plants were tested for the presence of ' $\mathrm{Ca}$. L. solanacearum' via $\mathrm{CPCR}$ using DNA extracted from leaf midrib samples collected from upper- and middle-tier leaves (Buchman et al. 2011b).

Retention of ' $\mathrm{Ca}$. L. solanacearum' in field-planted SLN. Thirty-six SLN plants that tested positive for ' $\mathrm{Ca}$. L. solanacearum' in the inoculation study described above were planted in the field in January 2013 inside field cages (soil emergence trap-headless insect rearing tent, 60 by 60 by $60 \mathrm{~cm}$, catalog number BT2007; BugDorm store, MegaView Science Co.) to avoid incidental infestation from resident $B$. cockerelli (Fig. 1). The plants remained completely caged throughout the entire period of study, except for collection of samples (e.g., leaves, roots, or stolons) and exposure of B. cockerelli adults for the acquisition study, which were done via the zippered opening on the side of the cages (Fig. 1, insert). One year later, several of the SLN plants lost their leaves due to extensive dieback and were gradually refoliating. Leaves from the upper and middle tier were also collected and DNA was extracted and tested for ' $\mathrm{Ca}$. L. solanacearum' using quantitative real-time PCR (qPCR). Roots and stolons were sampled by removing the top soil to a depth of $15 \mathrm{~cm}$. Thin, fibrous roots and stolons close to the stem were collected from 20 plants. DNA samples from the roots and stolons were extracted and pooled as one sample per plant and tested for ' $\mathrm{Ca}$. L. solanacearum' using qPCR, as described below. Psyllid acquisition assays were performed to confirm retention of the pathogen in field-planted ' $\mathrm{Ca}$. $\mathrm{L}$. solanacearum'-infected SLN. Seven ' $C a$. L. solanacearum'-free adults contained in 1,000- $\mu$ l pipette tips were released within white organza pouches tied to a middle- and lower-tier branch of each plant; each pouch surrounded at least three leaves. Acquisition assays were performed in March 2014 on 20 SLN plants that were inoculated with ' $C a$. L. solanacearum' the previous year and retained under field conditions. At 3 and 5 weeks after initial B. cockerelli exposure, the pouches were clipped off from the plants, adults were collected, and DNA was extracted and tested for the presence of ' $\mathrm{Ca}$. L. solanacearum' using qPCR.

B. cockerelli acquisition of ' $\mathrm{Ca}$. L. solanacearum' from SLN and transmission to potato under laboratory conditions. Twenty of the SLN plants that tested positive for ' $\mathrm{Ca}$. L. solanacearum' in the inoculation study described above were placed into two BugDorm insect cages ( 75 by 75 by $115 \mathrm{~cm}$, catalog number BD2400; MegaView Science Co.) with 10 plants each. Five hundred B. cockerelli adults from a ' $\mathrm{C} a$. L. solanacearum'-free colony were released inside each cage for acquiring ' $\mathrm{Ca}$. L. solanacearum' and allowed to remain on the 'Ca. L. solanacearum'-infected SLN plants in both cages. Periodically, starting 5 days after release, 10 to $15 \mathrm{~B}$. cockerelli adults were randomly drawn from each cage and tested for the presence of ' $\mathrm{Ca}$. L. solanacearum' using cPCR. Reliable detection of ' $\mathrm{Ca}$. L. solanacearum' in $B$. cockerelli has been reported by Crosslin et al. (2011) using cPCR and qPCR. After detecting ' $\mathrm{Ca}$. L. solanacearum' in the adults, three 3- to 4-week-old potato plants were placed within both cages to allow the adults to feed on potato. After 3 and 4 weeks of IAP, potato leaf samples were collected (three from top- and three

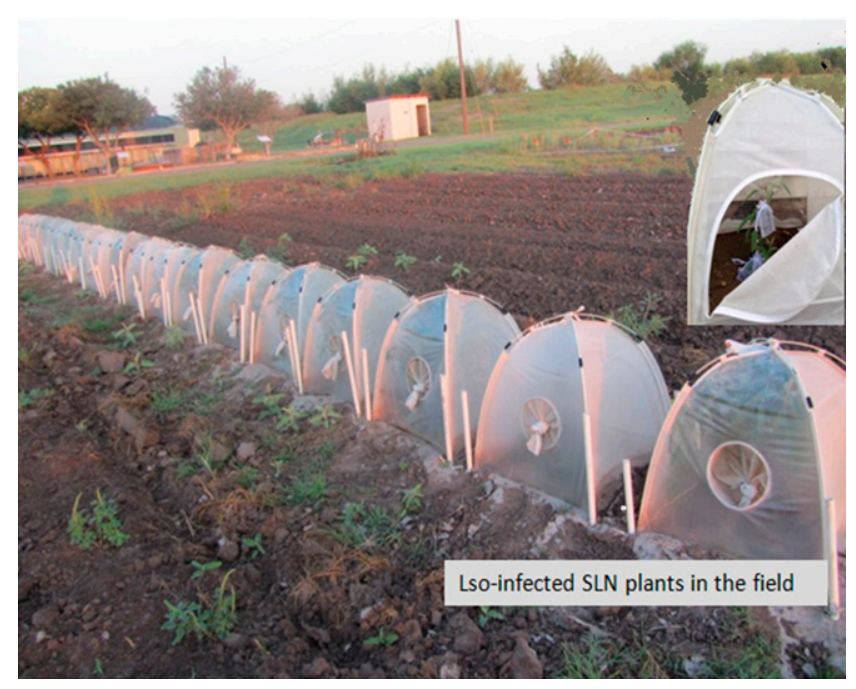

Fig. 1. 'Candidatus Liberibacter solanacearum'-infected silverleaf nightshade (SLN) plants in the field covered with soil emergence cages to avoid incidental psyllid infestation. Picture in insert shows white organza pouches with Bactericera cockerelli adults for insect acquisition studies. 
from middle-tier leaves) and pooled by plant (e.g., six plants = six samples) prior to being tested for ' $\mathrm{Ca}$. L. solanacearum' by cPCR, using DNA extracted from leaf midribs and petioles.

DNA extraction and PCR. Plant DNA extraction. Total genomic DNA was extracted from plant tissues using the cetyltrimethylammonium bromide (CTAB) method, as described previously by Buchman et al. (2011b), with modifications. A portion of the leaf midrib (or root or stolon) measuring approximately $0.3 \mathrm{~g}$ constituted a sample. Individual plant samples were washed thoroughly with water and dried on paper towels to ensure that they were free of B. cockerelli eggs or nymphs. Each sample was cut into small pieces, placed in a 2-ml tube (Lysing Matrix A; MP Biomedicals, Santa Ana, CA) with $1,000 \mu \mathrm{l}$ of plant extraction buffer, and pulverized for 4 min using a Mini Beadbeater-96 according to the manufacturer's specifications (BIOSPEC Products Inc., Bartlesville, OK). Tubes were centrifuged at $12,000 \mathrm{rpm}$ for $2 \mathrm{~min}$, and $300 \mu \mathrm{l}$ of the supernatant was pipetted into 1.5-ml microcentrifuge tubes (Thermo Fisher Scientific, Waltham, MA) containing $80 \mu$ l of lysozyme and incubated in a dry bath for $30 \mathrm{~min}$ at $37^{\circ} \mathrm{C}$. CTAB buffer $(500 \mu \mathrm{l})$ was added to the samples and incubated for $30 \mathrm{~min}$ at $65^{\circ} \mathrm{C}$. The samples were vortexed and centrifuged at $12,000 \mathrm{rpm}$ for $10 \mathrm{~min}$ after adding $500 \mu \mathrm{l}$ of chloroform. The supernatant was transferred to another $1.5-\mathrm{ml}$ microcentrifuge tube containing $1.3 \mu \mathrm{l}$ of glycogen and $500 \mu \mathrm{l}$ of isopropanol and placed on ice for $30 \mathrm{~min}$. The precipitated DNA pellet was rinsed with $70 \%$ ethanol and centrifuged at $12,000 \mathrm{rpm}$ for $2 \mathrm{~min}$. The ethanol was drained and the pellet was air dried at $37^{\circ} \mathrm{C}$ free of ethanol. The DNA pellet was then resuspended in $50 \mu$ l of nuclease-free water.

Psyllid DNA extraction. Total genomic DNA was extracted from individual psyllids using the CTAB extraction method described by Buchman et al. (2011b). Individual psyllids were crushed in $500 \mu \mathrm{l}$ of CTAB buffer in a $1.5-\mathrm{ml}$ microcentrifuge tubes (Thermo Fisher Scientific) using an Eppendorf micropestle (number 2317314; Sigma-Aldrich, St. Louis). Samples were incubated for $30 \mathrm{~min}$ at $65^{\circ} \mathrm{C}$, and $500 \mu \mathrm{l}$ of chloroform was added to samples at room temperature. The samples were vortexed and centrifuged for $3 \mathrm{~min}$ at $12,000 \mathrm{rpm}$. The supernatant was transferred to a new $1.5-\mathrm{ml}$ microcentrifuge tube containing $1.3 \mu \mathrm{l}$ of glycogen and $500 \mu \mathrm{l}$ of isopropanol and placed on ice for $30 \mathrm{~min}$. The precipitated DNA pellet was rinsed with ice-cold $70 \%$ ethanol and centrifuged at $12,000 \mathrm{rpm}$ for $2 \mathrm{~min}$. The ethanol was drained and the pellet was air dried, then resuspended in $100 \mu \mathrm{l}$ of nuclease-free water.

PCR assay for 'Ca. L. solanacearum' detection in plant and insect hosts. At the start of experiments during the year 2013, cPCR was

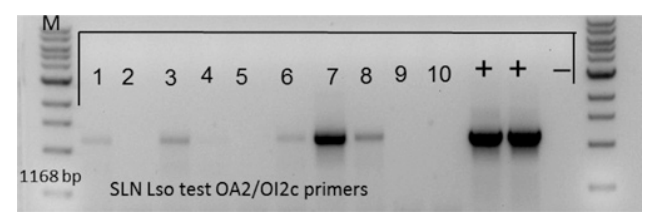

Fig. 2. Silverleaf nightshade (SLN) plant DNA tested for 'Candidatus Liberibacter solanacearum' using OA2/OI2C F/R primers. Lanes 1-10 indicate DNA extracted from individual SLN plants; + indicates positive control (e.g., an 'Ca. L. solanacearum'-infected plant sample) whereas - indicates no-template DNA (e.g., a water sample) Lane $\mathrm{M}=1-\mathrm{kb}$ DNA ladder (Invitrogen).

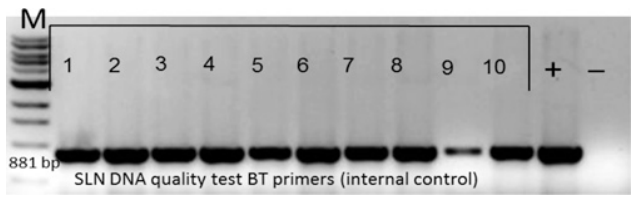

Fig. 3. Silverleaf nightshade (SLN) plant DNA tested for quality of the DNA extraction using Btub1F/R primers. Lanes 1-10 indicate individual SLN plants; + indicates positive control (e.g., an 'Candidatus Liberibacter solanacearum'-infected plant DNA sample) whereas - indicates no-template DNA (e.g., a water sample). Lane M = 1kb DNA ladder (Invitrogen). used to detect ' $\mathrm{Ca}$. L. solanacearum' in insect and plant samples. One year later, ' $C a$. L. solanacearum' was detected using qPCR methods, as described below, due to increasing volume of samples tested.

cPCR. 'Ca. L. solanacearum' detection was performed in a T100 Thermal Cycler (Bio-Rad Laboratories, Hercules, CA) in 21- $\mu 1$ reactions containing $9 \mu$ of $2 \times$ Phusion flash high-fidelity-PCR master mix (Thermo Fisher Scientific), $1 \mu \mathrm{l}$ each of OA2/OI2c primers (Liefting et al. 2009a) (10 pmol concentration), $9 \mu$ l of water, and $1 \mu \mathrm{l}$ of template DNA. Amplification of the $\beta$-tubulin gene Btub1F 5'-TGATTTCCAAGGTAAGGGAGGA-3' and Btub1R 5'-CATGTTGCTCTCGGCTTCAG-3' (Ravindran et al. 2011) indicated quality of DNA extracted from potato and SLN plant samples. Quality of B. cockerelli DNA extractions was confirmed using BC 28S F 5'-GCGAGGACTCAGTTTCGTGT-3' and BC 28S R 5'AGAGCTCGACTCGGATTGTC-3'(Hansen et al. 2008). PCR conditions for the above primer sets were $98^{\circ} \mathrm{C}$ for $10 \mathrm{~s}$, followed by 35 cycles of $98^{\circ} \mathrm{C}$ for $1 \mathrm{~s}, 60^{\circ} \mathrm{C}$ for $5 \mathrm{~s}, 72^{\circ} \mathrm{C}$ for $15 \mathrm{~s}$, and $72^{\circ} \mathrm{C}$ for $1 \mathrm{~min}$. The PCR products were visualized by electrophoresis on $1 \%$ agarose gels with ethidium bromide staining. The presence of the predicted 1,168-bp 16S ribosomal DNA band for the OA2/OI2c F/R primer pair was indicative of samples being ' $\mathrm{Ca}$. L. solanacearum' positive.

$q P C R$. qPCR reactions were performed using optical-grade $0.2-\mathrm{ml}$ thin-walled tube strips with individually attached optically clear flat caps (Temp Assure PCR 8-strips; USA Scientific, Inc., Ocala, FL). Detection and amplification of ' $\mathrm{Ca}$. L. solanacearum' were performed by simplex and multiplex PCR assays using the ZC primer-probe set (Li et al. 2009). The 25- $\mu$ l reaction mix consisted of $2 \mu \mathrm{l}$ of template DNA extract, $9 \mu \mathrm{l}$ of Phusion high-fidelity PCR Master Mix (Thermo Scientific, Pittsburg), $3 \mu$ l of $0.1 \mu \mathrm{M}$ $\mathrm{ZC}$ probe, $3 \mu \mathrm{l}$ of $0.25 \mu \mathrm{M}$ of sense and antisense primers, and $8 \mu \mathrm{l}$ of nuclease-free water. The amplification was carried out using a C1000 Touch thermal Cycler (CFX96 Real-Time System; Bio-Rad Laboratories). A plant mitochondrial cytochrome oxidase-based primer-probe set (Li et al. 2006) was used as internal quality control to verify quality of plant DNA extractions. Each qPCR consisted of 96 sample tubes and included the following controls: (i) known ' $\mathrm{Ca}$. L. solanacearum'-positive control DNA, (ii) ' $C a$. L. solanacearum'free plant or psyllid DNA, and (iii) nontemplate water control. The control reactions were run on separate eight-tube strips to avoid possible contamination of test samples. PCR cycling conditions were $98^{\circ} \mathrm{C}$ for $10 \mathrm{~s}$ followed by 35 cycles of $98^{\circ} \mathrm{C}$ for $1 \mathrm{~s}$ and $58^{\circ} \mathrm{C}$ for $10 \mathrm{~s}$ The cycle threshold $(\mathrm{Ct})$ value was determined by the BioRad CFX manager software and a cutoff value of 35 was established for samples to test positive for ' $\mathrm{Ca}$. L. solanacearum'.

\section{Results}

' $\mathbf{C a}$. L. solanacearum' inoculation to SLN plants. Out of the 100 SLN plants inoculated with ' $\mathrm{Ca}$. L. solanacearum'-infected $B$. cockerelli adults under laboratory conditions, 56 plants were confirmed to be ' $\mathrm{Ca}$. L. solanacearum' positive (Fig. 2) and, of those, 36 were used in subsequent retention and 20 in acquisition studies. The quality of DNA extractions were confirmed using Btub-F/R primers (Fig. 3).

Retention of ' $\mathrm{Ca}$. L. solanacearum' in field-planted SLN. Of the 36 of 56 ' $C a$. L. solanacearum'-positive SLN planted in the field in January 2013, many of the SLN plants had shed their foliage during the summer but most had refoliated by the following year. Twenty-eight plants had leaves for sampling in January 2014. Testing of leaf samples revealed that only 1 of 28 plant samples was found to be ' $\mathrm{Ca}$. L. solanacearum' positive, with a $\mathrm{Ct}$ value $<35$. Similar results of poor diagnosis of leaf samples have been previously reported (Levy et al. 2011; Wen et al. 2009). Further testing of lateral stolons and roots showed that 4 of 20 samples were ' $\mathrm{Ca}$. L. solanacearum' positive. Results of insect acquisition assays conducted on field-planted SLN that were inoculated with ' $C a$. L. solanacearum' a year ago are summarized and presented in Table 1. DNA extracted from seven $B$. cockerelli adults within each organza pouch (pooled sample) was tested for the presence of ' $\mathrm{Ca}$. L. solanacearum' and results showed that 15 of 17 samples tested positive for ' $C a$. L. 
Table 1. 'Candidatus Liberibacter solanacearum' acquisition by Bactericera cockerelli adults from field-planted, 'Ca. L. solanacearum'-infected SLN plants $^{\mathrm{a}}$

\begin{tabular}{lcc}
\hline & \multicolumn{2}{c}{ B. cockerelli release (March 2014) } \\
\cline { 2 - 3 } Sample & Ct value (3 WAE) & Ct value (5 WAE) \\
\hline 1 & 18.18 & 23.94 \\
2 & 15.87 & 17.68 \\
3 & 17.86 & 18.85 \\
4 & 25.78 & 28.01 \\
5 & 16.66 & 20.71 \\
6 & 33.91 & 22.79 \\
7 & 19.95 & 25.89 \\
8 & 18.54 & 21.61 \\
9 & 29.03 & 19.35 \\
10 & 22.49 & 21.60 \\
11 & 18.51 & 18.99 \\
12 & 22.13 & 25.71 \\
13 & 17.89 & 23.97 \\
14 & ND & 21.03 \\
15 & 33.93 & ND \\
16 & 24.32 & 25.21 \\
17 & $(38.24)$ & $(37.02)$ \\
Controls & & $\ldots$ \\
Infected $^{b}$ & 14.2 & $\ldots$ \\
Uninfected $_{\text {Water }}$ & ND & $\ldots$ \\
\hline Number & ND & $\ldots$ \\
\hline
\end{tabular}

a Number of polymerase chain reaction (PCR) cycles required to get fluorescence signal is represented by cycle threshold $(\mathrm{Ct})$ values obtained from real-time quantitative PCR performed on DNA samples of Bactericera cockerelli adults 3 and 5 weeks after initial exposure (WAE; collection $\mathrm{I}$ and II, respectively). $\mathrm{Ct}$ values $\leq 35$ are considered positive for ' $\mathrm{Ca}$. L. solanacearum'. CT values $>35$ are considered negative for ' $\mathrm{Ca}$. $\mathrm{L}$. solanacearum' and are shown in parentheses. ND = not detected and indicates that ' $C a$. L. solanacearum' could not be detected in these samples.

b 'Ca. L. solanacearum'-infected. solanacearum' both 3 and 5 weeks after initial exposure on ' $\mathrm{Ca}$. L. solanacearum'-infected SLN plants. In all assays, the Ct values ranged from 15.87 to 33.93 (Table 1).

$B$. cockerelli acquisition of ' $\mathrm{Ca}$. $\mathrm{L}$. solanacearum' from ' $\mathrm{Ca}$. $\mathrm{L}$. solanacearum'-infected SLN under laboratory conditions. In all, 20 of 56 ' $\mathrm{Ca}$. L. solanacearum'-positive plants generated earlier were used in this experiment. At 5 days after release of ' $\mathrm{Ca}$. L. solanacearum'-free $B$. cockerelli into cages of ' $\mathrm{Ca}$. L. solanacearum'infected SLN, 10 to 15 adults were randomly collected and tested for ' $\mathrm{Ca}$. L. solanacearum'. No psyllids tested ' $\mathrm{Ca}$. L. solanacearum' positive 5 days after release (Fig. 4). PCR amplification using the $\mathrm{BC} 28 \mathrm{~S} \mathrm{~F} / \mathrm{R}$ primers confirmed that quality of the DNA extraction was good (Fig. 5). In total, 1 of 10 adults tested positive 2 weeks later, and 3 of 14 and 4 of 15 adults tested positive 4 and 6 weeks later, respectively (Fig. 4). Thus, we report that $B$. cockerelli adults can acquire ' $C a$. L. solanacearum' within 2 weeks of exposure to ' $C a$. L. solanacearum'-infected SLN plants. Following ' $C a$. L. solanacearum' acquisition by psyllid adults from SLN, three 3- to 4-week-old potato plants were placed in each of the two cages, allowing the psyllids access to the potato plants for 3 weeks. No leaves from the six plants sampled 3 weeks after exposure to the psyllids tested positive for ' $\mathrm{Ca}$. L. solanacearum'. However, 4 weeks after IAP, one of six plants tested positive for ' $\mathrm{Ca}$. L. solanacearum' (i.e., 4 weeks after exposure to $B$. cockerelli) This result shows that psyllids acquiring ' $\mathrm{Ca}$. L. solanacearum' from ' $\mathrm{Ca}$. L. solanacearum'-infected SLN plants are able to transmit the pathogen to potato plants.

\section{Discussion}

Preliminary studies were conducted by Henne et al. (2010), inoculating wild solanaceous hosts with ' $\mathrm{Ca}$. L. solanacearum' using ' $\mathrm{Ca}$. L. solanacearum'-infected B. cockerelli adults. Test results revealed that, of the three wild hosts-SLN, buffalobur nightshade (Solanum rostrum), and Berlandier wolfberry (Lycium berlandierii) — buffalobur nightshade plants died quickly after being infected with ' $\mathrm{Ca}$. L.

5 days after release $-(0 / 10)$

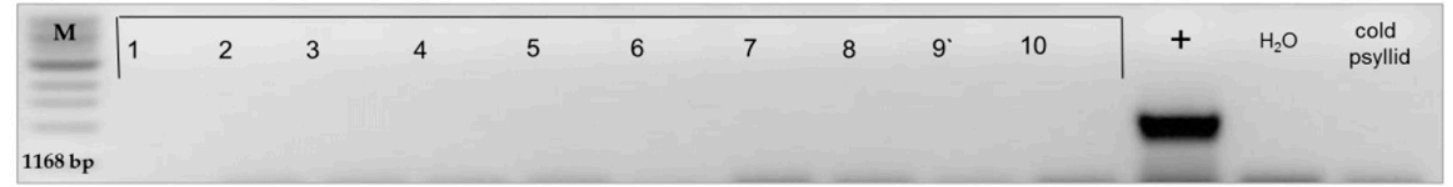

2 weeks after release- $(1 / 10)$

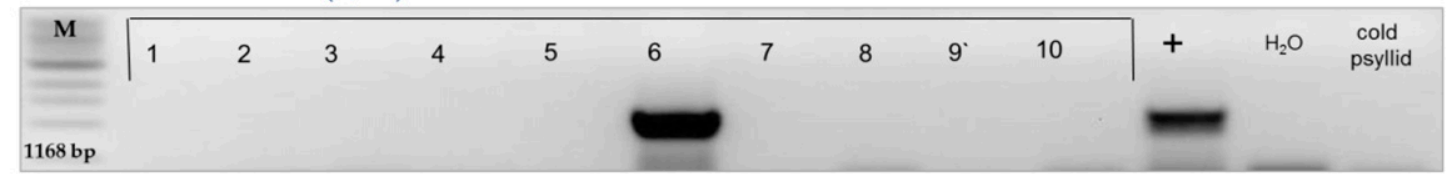

4 weeks after release- $(3 / 15)$

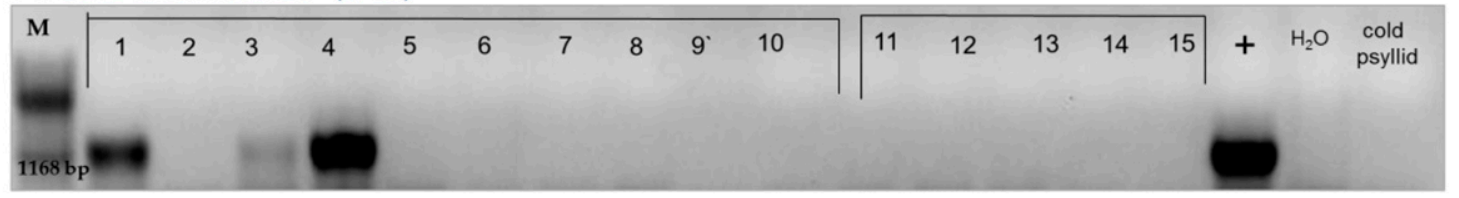

6 weeks after release $-(4 / 15)$

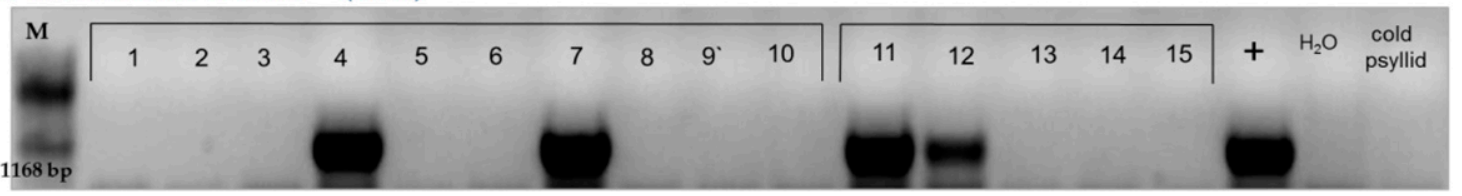

Fig. 4. 'Candidatus Liberibacter solanacearum' acquisition by Bactericera cockerelli adults collected 5 days and 2, 4, and 6 weeks after release on 'Ca. L. solanacearum'-infected silverleaf nightshade in the laboratory. Lanes 1-15 indicate individual B. cockerelli adults; + indicates positive control (e.g., a known 'Ca. L. solanacearum'-infected B. cockerelli sample) whereas " $\mathrm{H}_{2} \mathrm{O}$ " indicates no-template DNA (e.g., a water sample; "cold psyllid" indicates negative control (e.g., a known 'Ca. L. solanacearum'-free B. cockerelli DNA sample). Lane $\mathrm{M}=1-\mathrm{kb}$ DNA ladder (Invitrogen). 
solanacearum' whereas SLN harbored ' $C a$. L. solanacearum' but was not killed by the pathogen and motivated the present study.

Studies to evaluate SLN as a ZC pathogen reservoir host were initiated by inoculating ' $\mathrm{Ca}$. L. solanacearum' in SLN plants using ' $\mathrm{Ca}$. L. solanacearum'-infected $B$. cockerelli adults to determine acquisition, retention, and transmission of the pathogen from and to SLN. Although nymphs are reported to harbor the pathogen (Rush et al. 2010), adults are more efficient in transmitting ' $\mathrm{Ca}$. L. solanacearum' (Buchman et al. 2011b). Results of the present study confirm that ' $C a$. L. solanacearum' is transmitted to SLN through feeding by $B$. cockerelli adults and demonstrate for the first time that ' $\mathrm{Ca}$. L. solanacearum'-free $B$. cockerelli adults can acquire the pathogen from ' $C a$. L. solanacearum'-infected SLN and then infect potato. The present study further demonstrated that ' $\mathrm{Ca}$. L. solanacearum'infected SLN in the field can retain the bacterium from one potato planting season to the next. This was confirmed through testing of above- and belowground plant samples and also through acquisition assays by ' $C a$. L. solanacearum'-free $B$. cockerelli adults. Taken together, these findings demonstrate that SLN can serve as a reservoir host, carrying the pathogen over the summer and into the next field season. Given the abundance of this weedy species in the LRGV, SLN may be an overlooked source of primary inoculum bridging potato cropping cycles.

As previously reported, 'Ca. L. solanacearum' detection in leaves of potentially infected plants using PCR-based methods is relatively unreliable (Wen et al. 2009) and could possibly be attributed to low frequency of ' $\mathrm{Ca}$. L. solanacearum' infection in SLN and potato (Thinakaran et al. 2013). For example, Levy et al. (2011) demonstrated that, although plants may become infected by ' $\mathrm{Ca}$. L. solanacearum' after only 1 week of insect feeding, ' $C a$. L. solanacearum' may not be detected in leaf midrib or petiole samples until 2 to 3 weeks after infestation, and then most frequently in younger leaves (e.g., upper- and middle-tier leaves). One of six samples from potato plants tested 4 weeks after exposure to ' $\mathrm{Ca}$. L. solanacearum'infected B. cockerelli adults (e.g., having acquired ' $C a$. L. solanacearum' from infected SLN) was positive for ' $\mathrm{Ca}$. L. solanacearum'. Based on this, we report that $B$. cockerelli insects acquiring ' $C a$. L. solanacearum' from ' $\mathrm{Ca}$. L. solanacearum'-infected SLN plants are able to transfer the pathogen to potato plants but at a low frequency, as determined by PCR. Again, it is likely that the actual rate of plant infection may have been higher. The emphasis of this study was to demonstrate whether SLN plants are epidemiologically important reservoir hosts of the pathogen. Assessing rate or magnitude of ' $\mathrm{Ca}$. L. solanacearum' transmission is beyond the scope of this study and will form part of a separate study designed for the purpose. Amplification of the $\beta$-tubulin gene was used as a positive control to verify the quality of DNA extractions (Ravindran et al. 2011). The primer pairs OA2/OI2c were used for ' $C a$. L. solanacearum' detection; these are currently widely used and shown to provide relatively reliable detection (Liefting et al. 2009b). However, Crosslin et al. (2011) clearly demonstrated unambiguous detection of ' $C a$. L. solanacearum' in DNA samples of $B$. cockerelli adults using conventional and quantitative real-time PCR methods. This was also evident in our observations from insect acquisition assays (Table 1; Fig. 4).

Interestingly, ' $\mathrm{Ca}$. L. solanacearum' was detected more frequently in roots and stolons of field-planted SLN compared with the leaf samples. Consistent with the hypothesis that bacterial titers may be higher in roots and or stolons, 1/5 of the surviving plants tested positive for ' $\mathrm{Ca}$. L. solanacearum' in the pooled stolon or root samples but only $1 / 28$ tested positive for ' $\mathrm{Ca}$. L. solanacearum' in the leaf

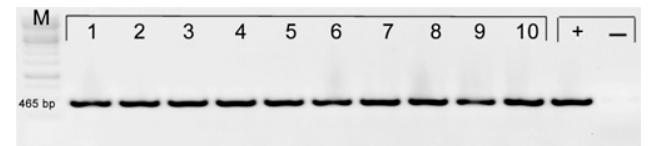

Fig. 5. DNA quality of Bactericera cockerelli samples (collected after 5 days) tested for 'Candidatus Liberibacter solanacearum' using BC 28S F/R primers. Lanes 1-10 indicate individual $B$. cockerelli samples; + indicates positive control (e.g., a known 'Ca. L. solanacearum'-infected $B$. cockerelli sample) whereas - indicates notemplate DNA (e.g., a water sample). Lane $\mathrm{M}=1-\mathrm{kb}$ DNA ladder (Invitrogen). midrib samples. Furthermore, B. cockerelli adults that fed on ' $C a$. L. solanacearum'-infected SLN acquired the pathogen. These results confirmed that ' $\mathrm{Ca}$. L. solanacearum' was present in SLN at titers high enough to be acquired by insects but perhaps too low for PCR detection in the leaves sampled. Similar reports have been made of more reliable detection of ' $\mathrm{Ca}$. Liberibacter' strains in the roots as compared with leaves of citrus (Johnson et al. 2014; Kunta et al. 2014) and other solanaceous hosts (Wen et al. 2009). These results demonstrated that ' $C a$. L. solanacearum' was retained within SLN plants from one cropping season to the next despite dieback of aboveground tissues during the summer months.

If bacterial translocation patterns follow source-to-sink dynamics within the phloem, it can be hypothesized that the highest ' $\mathrm{Ca}$. L. solanacearum' titers might be within the most significant resource sinks, including metabolically active roots or storage tissues such as stolons and tubers. Under natural conditions, SLN grows as a shrub, putting forth stolons that give rise to new daughter plants following death or separation from the mother plant (Fig. 6). This growth habit is somewhat similar to potato in that both SLN and potato reproduce vegetatively via underground stems (stolons versus tubers in the case of SLN and potato, respectively) and sexually by producing seed. The distribution of SLN plants is often observed as patches (J. Thinakaran, personal observation), suggesting that reproduction through vegetative means is common. The plants also have a very deep taproot system that can grow up to $1 \mathrm{~m}$ long, which makes the plant hardy and difficult to eradicate. A longstanding question for understanding the epidemiology of $\mathrm{ZC}$ has been identifying the source of the ' $C a$. L. solanacearum' primary inoculum. A central hypothesis has been that ' $\mathrm{Ca}$. L. solanacearum' is conveyed to the LRGV annually by migrations of ' $\mathrm{Ca}$. L. solanacearum'-infected $\mathrm{B}$. cockerelli adults, rather than via population surges of ' $\mathrm{Ca}$. L. solanacearum'-infected $B$. cockerelli residents. In support of this hypothesis, previous research suggests that, at the end of the potato cropping season, B. cockerelli numbers in the LRGV are greatly diminished (Thinakaran 2014), with potato psyllids migrating northward from their breeding areas in South Texas as reported by Romney (1939) and Janes (1939). Furthermore, remaining psyllids may not retain ' $\mathrm{Ca}$. L. solanacearum' because it has been reported that ' $C a$. L. solanacearum' is sensitive to temperatures exceeding $35^{\circ} \mathrm{C}$ (Munyaneza et al. 2012), temperatures that commonly occur during summers in the LRGV. In the absence of ' $C a$. L. solanacearum'-infected $B$. cockerelli adults, primary inoculum would need to come in with ' $\mathrm{Ca}$. L. solanacearum'-infected $B$. cockerelli or be acquired locally by arriving ' $\mathrm{Ca}$. L. solanacearum'free migrant adults. Although migration of ' $\mathrm{Ca}$. L. solanacearum'infected adults may be the principal source of primary inoculum, our findings indicate that SLN may serve as a reservoir of the pathogen that can be acquired by ' $C a$. L. solanacearum'-free resident and migrant $B$. cockerelli populations, thus increasing the probability of ZC incidence.

The importance of alternative host plants, especially solanaceous weeds that may contribute to epidemiology of ZC by serving as refuges for the insect pest and reservoirs for the pathogen in the absence of cultivated species, is emphasized. The results presented here

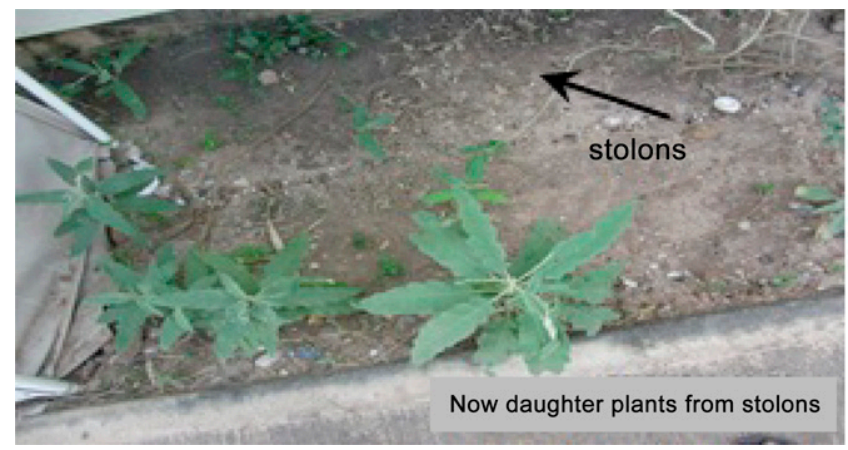

Fig. 6. Growth of silverleaf nightshade in the field. Mother plants die, giving rise to daughter plants from stolons. 
demonstrate that SLN can serve as a pathogen reservoir bridging crop cycles. Future work is necessary to determine whether ' $\mathrm{Ca}$. $\mathrm{L}$. solanacearum' infection can be transferred to and retained within daughter plants and whether, once infected, ' $C a$. L. solanacearum' can persist within SLN for more than one growing season. Given the abundance of SLN in the LRGV, these findings, coupled with the potential for long-term maintenance of the pathogen in clonal populations, clearly indicate the importance of eradicating SLN plants to prevent them from serving as a source of primary inoculum for vector transmission of ' $\mathrm{Ca}$. L. solanacearum' to potato fields. Identification of potential pathogen reservoirs in other potato-growing regions may lead to a better understanding of the ZC epidemiology, especially as the disease continues to spread to new potato-growing regions.

\section{Acknowledgments}

We thank T. Salazar, A. Reyes Martinez, A. Pena, and E. Huerta for technical assistance; and J. C. Miller, J. G. Levy, A. Ravindran, C. Tamborindeguy, and D. Scheuring for their guidance and support. Funding was provided by USDA RAMP grant 2009-51101-05892 and USDA SCRI grant 2009-51181-20178.

\section{Literature Cited}

Buchman, J. L., Heilman, B. E., and Munyaneza, J. E. 2011a. Effects of Liberibacter-infective Bactericera cockerelli (Hemiptera: Triozidae) density on zebra chip potato disease incidence, potato yield and tuber processing quality. J. Econ. Entomol. 104:1783-1792.

Buchman, J. L., Sengoda, V. G., and Munyaneza, J. E. 2011b. Vector transmission efficiency of Liberibacter by Bactericera cockerelli (Hemiptera: Triozidae) in zebra chip potato disease: Effects of psyllid life stage and inoculation access period. J. Econ. Entomol. 104:1486-1495.

Crawford, D. L. 1914. A monograph of the jumping plant lice or psyllidae of the new world. U. S. Natl. Museum Bull. 85:186.

Crosslin, J. E., Lin, H., and Munyaneza, J. E. 2011. Detection of 'Candidatus Liberibacter solanacearum' in the potato psyllid, Bactericera cockerelli (Šulc), by conventional and real-time PCR. Southwest. Entomol. 36:125-135.

Crosslin, J. M., Hamm, P. B., and Munyaneza, J. E. 2012a. First report of zebra chip disease and 'Candidatus Liberibacter solanacearum' on potatoes in Oregon and Washington State. Plant Dis. 96:452.

Crosslin, J. M., Munyaneza, J. E., Brown, J. K., and Liefting, L. W. 2010. Potato zebra chip disease: A phytopathological tale. Online publication. Plant Health Prog. doi: 10.1094/PHP-2010-0317-1001-RV

Crosslin, J. M., Olsen, N., and Nolte, P. 2012b. First report of zebra chip disease and "Candidatus Liberibacter solanacearum" on potatoes in Idaho. Plant Dis. 96:453.

Essig, E. O. 1917. The tomato and laurel psyllids. J. Econ. Entomol. 10:433-444.

Hansen, A. K., Trumble, J. T., Stouthamer, R., and Paine, T. D. 2008. A new huanglongbing (HLB) species 'Candidatus Liberibacter psyllaurous', found to infect tomato and potato, is vectored by the psyllid Bactericera cockerelli (Sulc). Appl. Environ. Microbiol. 74:5862-5865.

Henne, D. C., Paetzold, L., Workneh, F., and Rush, C. M. 2010. Evaluation of potato psyllid cold tolerance, overwintering survival, sticky trap sampling, and effects of Liberibacter on potato psyllid alternate host plants. Pages 149-153 in: Proc. 10th Annu. Zebra Chip Rep. Sess. Dallas. F. Workneh and C. M. Rush, eds.

Janes, M. J. 1939. Observations on the potato psyllid in southwest Texas. J. Econ. Entomol. 32:468.

Johnson, E. G., Wu, J., Bright, D. B., and Graham, J. H. 2014. Association of 'Candidatus Liberibacter asiaticus' root infection, but not phloem plugging with root loss on huanglongbing-affected trees prior to appearance of foliar symptoms. Plant Pathol. 63:290-298.

Knowlton, G. F., and Thomas, W. L. 1934. Host plants of the potato psyllid. J. Econ. Entomol. 27:547.

Kunta, M. B., Viloria, Z., Rio, H. S., and Louzada, E. S. 2014. Diverse DNA extraction methods and PCR primers for detection of Huanglongbing-associated bacteria from roots of 'Valencia' sweet orange rootstock. Sci. Hortic. 178:23-30.

Levy, J., Ravindran, A., Gross, D., Tamborindeguy, C., and Pierson, E. 2011. Translocation of 'Candidatus Liberibacter solanacearum', the zebra chip pathogen, in potato and tomato. Phytopathology 101:1285-1291.
Li, W., Abad, J. A., French-Monar, R. D., Rascoe, J., Wen, A., Gudmestad, N. C. Secor, G. A., Lee, I. M., and Levy, L. 2009. Multiplex real-time PCR for detection, identification and quantification of 'Candidatus Liberibacter solanacearum' in potato plants with zebra chip. J. Microbiol. Methods 78: 59-65.

Li, W., Hartung, J. S., and Levy, L. 2006. Quantitative real-time PCR for detection and identification of Candidatus Liberibacter species associated with citrus huanglongbing. J. Microbiol. Methods 66:104-115.

Liefting, L. W., Perez-Egusquiza, Z. C., Clover, G. R. G., and Anderson, J. A. D. 2008. A new 'Candidatus Liberibacter' species in Solanum tuberosum in New Zealand. Plant Dis. 92:1474.

Liefting, L. W., Sutherland, P. W., Ward, L. I., Paice, K. L., Weir, B. S., and Clover, R. G. 2009a. A new 'Candidatus Liberibacter' species associated with diseases of solanaceous crops. Plant Dis. 93:208-214.

Liefting, L. W., Weir, B. S., Pennycook, S. R., and Clover, G. R. G. 2009b. 'Candidatus Liberibacter solanacearum', associated with plants in the family Solanaceae. Int. J. Syst. Evol. Microbiol. 59:2274-2276.

Munyaneza, J. E. 2012. Zebra chip disease of potato: Biology, Epidemiology, and Management. Am. J. Potato Res. 89:329-350.

Munyaneza, J. E., Crosslin, J. M., and Upton, J. E. 2007a. Association of Bactericera cockerelli (Homoptera: Psyllidae) with "zebra chip", a new potato disease in southwestern United States and Mexico. J. Econ. Entomol. 100:656-663.

Munyaneza, J. E., Goolsby, J. A., Crosslin, J. M., and Upton, J. E. 2007b. Further evidence that zebra chip potato disease in the lower Rio Grande Valley of Texas is associated with Bactericera cockerelli. Subtrop. Plant Sci. 59:30-39.

Munyaneza, J. E., Sengoda, V. G., Buchman, J. L., and Fischer, T. W. 2012. Effects of temperature on 'Candidatus Liberibacter solanacearum' and zebra chip potato disease symptom development. Plant Dis. 96:18-23.

Pletch, D. J. 1947. The potato psyllid Paratrioza cockerelli (Sulc), its biology and control. Mont. Agric. Exp. Stn. Bull. 446.

Ravindran, A., Levy, J., Pierson, E., and Gross, D. 2011. Development of primers for improved detection of the potato zebra chip pathogen, 'Candidatus Liberibacter solanacearum'. Plant Dis. 95:1542-1546.

Robinson, A. F., Orr, C. C., and Heintz, C. E. 1978. Distribution of Nothanguina phyllobia and its potential as a biological control agent of silverleaf nightshade. J. Nematol. 10:361-366.

Romney, V. E. 1939. Breeding areas of the tomato psyllid, Paratrioza cockerelli (Sulc). J. Econ. Entomol. 32:150.

Rush, C. M., Henne, D. C., Workneh, F., and Paetzold, L. 2010. Investigating titer variation of 'Candidatus Liberibacter solanacearum' in individual psyllid populations. Pages 19-23 in: Proc. 10th Annu. Zebra Chip Rep. Sess. Dallas. F. Workneh and C. M. Rush, eds.

Secor, G. A., and Rivera-Varas, V. V. 2004. Emerging diseases of cultivated potato and their impact on Latin America. Rev. Latinoam. Papa 1 (Suppl.):1-8.

Secor, G. A., Rivera-Varas, V., Abad, J. A., Lee, I. M., Clover, G. R. G., Liefting, L. W., Li, X., and De Boer, S. H. 2009. Association of 'Candidatus Liberibacter solanacearum' with zebra chip disease of potato established by graft and psyllid transmission, electron microscopy, and PCR. Plant Dis. 93:574-583.

Sengoda, G. S., Buchman, J. L., Henne, D. C., Pappu, H. R., and Munyaneza, J. E. 2013. 'Candidatus Liberibacter solanacearum' titer over time in Bactericera cockerelli (Hemiptera: Triozidae) after acquisition from infected potato and tomato plants. J. Econ. Entomol. 106:1964-1972.

Thinakaran, J. 2014. Evaluation of Bactericera cockerelli (Sulc) (Hemiptera: Triozidae) host preferences, adaptation, behavior, and transmission of 'Candidatus Liberibacter solanacearum' among wild and cultivated solanaceous hosts in the Lower Rio Grande Valley of Texas. Ph.D. Thesis. Texas A\&M University, College Station, TX.

Thinakaran, J., Pierson, E., Kunta, M., and Henne, D. 2013. Role of solanaceous alternative hosts in the transmission of the bacterial pathogen, 'Candidatus Liberibacter solanacearum' in the Lower Rio Grande Valley of Texas. Pages 147-151 in: Proc. 13th Annu. Zebra Chip Rep. Sess. San Antonio, TX.

Wallis, R. L. 1955. Ecological studies on the potato psyllid as a pest of potatoes. Tech. Bull. U. S. Dep. Agric. 1107:1-24.

Wen, A., Malik, I., Alvarado, V. Y., Pasche, J. S., Wang, X., Li, W., Levy, L., Lin, H., Scholthof, H. B., Mirkov, T. E., Rush, C. M., and Gudmestad, N. C. 2009. Detection, distribution, and genetic variability of 'Candidatus Liberibacter' species associated with zebra complex disease of potato in North America. Plant Dis. 93:1102-1115. 